\title{
Analisis Pemahaman Guru IPA se-Kecamatan Lima Kaum terhadap Pelaksanaan Standar Proses dan Standar Penilaian Kurikulum 2013
}

\author{
Yudistia Ariany ${ }^{1)}, \operatorname{Ardi}^{2}$, Yosi Laila Rahmi ${ }^{3)}$ \\ ${ }^{1)}$ Program Studi Pendidikan Biologi FMIPA Universitas Negeri Padang \\ ${ }^{2,3)}$ Staf Pengajar Jurusan Biologi, FMIPA Universitas Negeri Padang \\ yudistiaariany381@gmail.com ${ }^{1)}$,ihfawa@gmail.com ${ }^{2}$, yosibio@fmipa.unp.ac.id ${ }^{3)}$
}

\begin{abstract}
In the 2013 curriculum the learning process uses $21^{\text {st }}$ century skills, while for the assessment process uses authentic assessment. Based on the observation of class VII SMP Negeri in Lima Kaum Tanah Datar district, the teachers in the school have not fully implemented the Curriculum 2013. This resulted in a gap in the compliance of National Education Standards, especially on process standards and assessment standards.The aim of this research is a describe the understanding of science teachers in implementing the 2013 Curriculum in the class VII especially on standard process and assessment standard. This research was conducted in junior high school in Kecamatan Lima Kaum Tanah Datar. The population in this research is science teacher in class VII consisting of 8 science teachers. The sampling technique used is total sampling. Data collection techniques used questionnaires and document analysis. The data obtained were analyzed using percentage technique and made according to the descriptive sub indicator.The results revealed the understanding of science teachers on the implementation of Curriculum 2013 class VII in SMP Negeri Se-Kecamatan Lima Kaum Tanah Datar. 1. Understanding of science teachers on the implementation of Curriculum 2013 based on process standard that is $80,5 \%$ with good criteria. 2. Understanding of science teachers on the implementation of Curriculum 2013 based on the standard assessment is $83.4 \%$ with good criteria.
\end{abstract}

Keywords : Understanding, Process Standard, Assessment Standard, Curriculum 2013

This is an open access article distributed under the Creative Commons 4.0 Attribution License, which permits unrestricted use, distribution, and reproduction in any medium, provided the original work is properly cited $\odot 2018$ by author and Universitas Negeri Padang.

\section{PENDAHULUAN}

Dalam rangka peningkatan mutu pendidikan dasar dan menengah Kementerian Pendidikandan Kebudayaan (Kemendikbud) pada tahun 2013 telah melakukan pengembangan kurikulum, dari Kurikulum Tingkat Satuan Pendidikan (KTSP) pada tahun 2006 menjadi Kurikulum 2013. Menurut Afifah, Sayuti, dan Pramono (2017) "Kurikulum 2013 adalah kurikulum yang merupakan lanjutan pengembangan kurikulum sebelumnya yang mencakup kompetensi sikap, pengetahuan, dan keterampilan se-cara terpadu". Pembaharuan proses pembelajaran Kurikulum 2013 terletak pada pembelajaran yang menekankan keaktifan peserta didik secara mandiri.

Hal ini memberikan perbedaan antara Kurikulum 2013 dengan kurikulum sebelumnya yaitu perubahan proses pembelajaran dan proses penilaian. Menurut Vusparatih (2014) "Perubahan proses pembelajaran Kurikulum 2013 adalah peserta didik tidak diberitahu tetapi mencari tahu, sedangkan proses penilaian tidak lagi berbasis output tetapi menjadi berbasis proses dan output". Berdasarkan Hal ini, proses pembelajaran dan penilaian ini menuntut proses pembelajaran yang berpusat pada peserta didik sehingga tercipta suasana belajar yang aktif.

Pada saat terjadi perubahan kurikulum guru harus memahami peranannya dalam menjalankan kurikulum tersebut. Menurut Mulyasa (2014) "Perubahan kurikulum seharusnya ditunjang oleh guru yang betul-betul menguasai isi atau substansi kurikulum, yang menyangkut kompetensi profesional dan pedagogik, khususnya berkaitan dengan materi pembelajaran yang harus diolah dalam membentuk karakter dan kompetensi peserta didik". Rahmi dan Alberida (2017) menyatakan perubahan yang terjadi pada kurikulum akan mempengaruhi proses pembelajaran di sekolah. Guru sebagai ujung tombak pelaksana kurikulum hendaknya memiliki kompetensi untuk mengimplementasikan kurikulum dalam proses pembelajaran agar tercapainya tujuan pendidikan. Kurikulum 2013 membawa perubahan 
mendasar dalam pembelajaran. Oleh karena itu, guru dituntut untuk menyiapkan dirinya dalam melaksanakan Kurikulum 2013.

Pembelajaran pada Kurikulum 2013 mengharuskan Ilmu Pengetahuan Alam (IPA) di jenjang pendidikan SMP/MTS diajarkan secara terpadu. Lukum (2015) menyatakan bahwa pembelajaran IPA pada hakikatnya merupakan suatu pendekatan pembelajaran yang dapat membiasakan peserta didik secara individual ataupun kelompok dengan aktif mengeksplorasi, mengelaborasi, mengkonfirmasi, dan mengomunikasikan hasilnya. Oleh sebab itu, pembelajaran IPA yang dikembangkan dalam Kurikulum 2013 adalah IPA sebagai mata pelajaran integrative science, bukan sebagai pendidikan disiplin ilmu.

Kurikulum 2013 merupakan gerbang awal untuk memasuki pendidikan di Abad 21. Pendidikan Abad 21 menuntut kemampuan guru untuk mencari tahu pengetahuan sebanyakbanyaknya melalui perkembangan teknologi dan informasi.Menurut Wijaya, Y.E, Sudjimat, A.D dan Nyoto, A (2016) "Keterampilan yang menjadi fokus kompetensi pembelajaran pada Abad 21 adalah keterampilan dalam menguasai media teknologi dan infromasi (TIK)". Sedangkan peserta didik lebih didorong untuk memiliki tanggung jawab kepada lingkungan danmemiliki kemampuan berpikir tingkat tinggi. Pada Kurikulum 2013 proses pembelajaran menggunakan kompetensi kecakapan Abad 21. Menurut Ditjen Pendidikan Dasar dan Menengah (2017) "Pembelajaran Abad 21 merupakan pembelajaran yang mengintegrasikan kemampuan literasi, kecakapan pengetahuan, keterampilan, dan sikap, serta penguasaan terhadap teknologi”. Ber-dasarkan hal ini, maka angka kompetensi Abad 21 menjadi pijakan di dalam pengembangan Kurikulum 2013. pergeseran paradigma belajar Abad 21 dan ker

Selainitu, untuk proses penilaian yang di pakai dalam Kurikulum 2013pada proses pembelajaran IPA adalah penilaian autentik. Menurut Kunandar (2015) "Penilaian autentik ada lah kegiatan menilai peserta didik yang menekankan pada apa yang seharusnya dinilai, baik proses maupun hasil dengan berbagai instrumen penilaian yang disesuaikan dengan tuntutan kompetensi yang ada di Kompetensi Inti (KI) dan Kompetensi Dasar (KD)". Penilaian autentik harus ditekankan pada ketiga ranah yang mencakup sikap, pengetahuan dan keterampilan secara menyeluruh sesuai dengan tu juan proses pembelajaran dan hasil.

Berdasarkan observasi yang penulis lakukan dengan guru IPA kelas VII SMP Negeri se-Kecamatan Lima Kaum padabulan Mei 2017, terdapat empat SMP Negeri di kecamatan Lima Kaum yang telah menerapkan Kurikulum 2013 yaitu SMP Negeri 1 Batusangkar, SMP Negeri 2 Batusangkar, SMP Negeri 3 Batusangkar dan SMP Negeri 5 Batusangkar. Dalam pelaksanaannya sekolah SMP Negeri 1 Batusangkar dan SMP Negeri 2 Batusangkar telah menerapkan Kurikulum 2013 kurang lebih selama tiga tahun, SMP Negeri 5 Batusangkar menerapkan Kurikulum 2013 pada tahun 2016, sedangkan SMP Negeri 3 Batusangkar menerapkan Kurikulum 2013 pada semester ganjil tahun 2017.

Sekolah-sekolah SMP Negeri di Kecamatan Lima Kaum Batusangkar belum sepenuhnya mengimplementasikan Kurikulum 2013 berdasarkan Standar Nasional Pendidikan (SNP) yang telah ditetapkan pemerintah. Oleh karena itu masih terdapat kekurangan dan kelemahan pelaksanaannya. Kekurangan dan kelemahan pelaksanaan Kurikulum 2013, terlihat dari adanya kesenjangan pada keterpenuhan Standar Nasional Pendidikan terutama pada standar proses dan standar penilaian.

Standar proses pembelajaran IPA di Indonesia mengacu pada standar proses pembelajaran sesuai Permendikbud Nomor 22 Tahun 2016. Merujuk pada standar proses, perubahan pembelajaran dan mindset para guru didasarkan pada kecakapan Abad 21. Standar proses merupakan kriteria mengenai pelaksanaan pembelajaran yang meliputi a. perencanaan pembelajaran: silabus, RPP, dan prinsip penyusunan RPP. b. pelaksanaan pembelajaran: kegiatan pendahuluan, kegiatan inti, dan kegiatan penutup, c. penilaian proses dan hasil pembelajaran. Guru di lapangan belum sepenuhnya menerapkan standar proses dalam proses pembelajaran.

Sedangkan pada standar penilaian mengacu pada standar penilaian pendidikan sesuai Permendikbud Nomor 23 Tahun 2016, standar penilaian merupakan kriteria mengenai lingkup penilaian, tujuan penilaian, prinsip penilaian, bentuk penilaian, mekanisme penilaian, prosedur penilaian, dan instrumen penilaian hasil belajar peserta didik yang digunakan sebagai dasar dalam penilaian hasil belajar peserta didik pada pendidikan dasar dan 
pendidikan menengah. Guru di lapangan belum sepenuhnya menerapkan standar penilaian dalam proses pembelajaran. Hal-hal tersebut menyebabkan tujuan pembelajaran dan penilaian tidak terpenuhi.

Berdasarkan permasalahan yang penulis temukan di SMP Negeri se-Kecamatan Lima Kaum, maka untuk mengetahui lebih lanjut pelaksanaan Kurikulum 2013 ini, penulis melakukan penelitian tentang pemahaman guru IPA terhadap pelaksanaan Kurikulum 2013 kelas VII SMP Negeri se-Kecamatan Lima Kaum Tahun 2017/2018.

\section{METODE PENELITIAN}

Penelitian ini merupakan penelitian deskriptif. Penelitian ini dilakukan di empat SMP Negeri se-Kecamatan Lima Kaum Kabupaten Tanah Datar. Dalam hal ini penulis menetapkan 4 sekolah yaitu SMP Negeri 1 Batusangkar, SMP Negeri 2 Batusagkar, SMP Negeri 3 Batusangkar, dan SMP Negeri 5 Batusangkar karena telah menjalankan Kurikulum 2013.

Data dalam penelitian ini adalah data primer yang diperoleh langsung dari angket yang disebarkan kepada sampel penelitian. Sampel dalam penelitia ini yaitu seluruh guru yang mengajar pelajaran IPA di kelas VII yang berjumlah 8 orang guru. Teknik pengumpulan data yang digunakan dalam pengambilan sampel adalah total sampling.

Teknik analisis data yang digunakan adalah analisis deskriptif persentase. Deskriptif presentase ini diolah dengan cara frekuensi dibagi dengan jumlah responden dikali $100 \%$ seperti yang dikemukakan Sudjana (2005) sebagai berikut:

$$
\mathrm{P}=\mathrm{F} / \mathrm{N} \times 100 \%
$$

Keterangan $\mathrm{P}$ adalah presentase jawaban, $\mathrm{F}$ adalah frekuensi nilai yang diperoleh dari seluruh item, $\mathrm{N}$ adalah jumlah responden, dan $100 \%$ adalah konstanta.

Kemudian untuk memberikan kriteria pada masing-masing indikator, digunakan klasifikasi yang dimodifikasi dari Arikunto (2007) dengan rentangan sebagai berikut ini.

$$
\begin{array}{ll}
25-50 & =\text { Kurang } \\
51-75 & =\text { Cukup } \\
76-100 & =\text { Baik }
\end{array}
$$

\section{HASIL DAN PEMBAHASAN}

\section{Hasil Penelitian}

Data hasil penelitian ini adalah jawaban angket tentang pemahaman guru IPA terhadap pelaksanaan Kurikulum 2013 kelas VII SMP Negeri di Kecamatan Lima KaumTahun 2017/2018 oleh 8 orang guru IPA kelas VII. Berdasarkan angket yang telah peneliti sebarkan, maka secara umum dapat diperoleh data pemahaman terhadap pelaksanaan Kurikulum 2013 dari segi standar proses dan standar pe-

\begin{tabular}{|c|c|c|c|}
\hline No & $\begin{array}{l}\text { Pemahaman ter- } \\
\text { hadap pelaksanaan } \\
\text { Kurikulum } 2013 \\
\end{array}$ & $\begin{array}{l}\text { Presen- } \\
\text { tase }\end{array}$ & Kriteria \\
\hline 1. & $\begin{array}{l}\text { Tujuan Kurikulum } \\
2013\end{array}$ & $87,5 \%$ & Baik \\
\hline 2. & $\begin{array}{l}\text { Efektivitas pelaksa- } \\
\text { naan Kurikulum } \\
2013\end{array}$ & $75 \%$ & Cukup \\
\hline 3. & $\begin{array}{l}\text { Perubahan proses } \\
\text { pembelajaran }\end{array}$ & $75 \%$ & Cukup \\
\hline 4. & $\begin{array}{l}\text { Proses pem- } \\
\text { belajaran kecakap-an } \\
\text { Abad } 21\end{array}$ & $65,6 \%$ & Cukup \\
\hline 5. & $\begin{array}{l}\text { Tujuan pem- } \\
\text { belajaran kecakap-an } \\
\text { Abad } 21\end{array}$ & $62,5 \%$ & Cukup \\
\hline & Rata-rata & $73 \%$ & Cukup \\
\hline
\end{tabular}
nilaian.

Tabel 1. Pemahaman Guru IPA terhadap Kurikulum 2013

\begin{tabular}{|c|c|c|c|}
\hline No & $\begin{array}{l}\text { Pemahaman ter- } \\
\text { hadap pelaksanaan } \\
\text { Kurikulum } 2013 \\
\end{array}$ & $\begin{array}{l}\text { Pre- } \\
\text { sen- } \\
\text { tase }\end{array}$ & Kriteria \\
\hline 1. & Membuat RPP & $100 \%$ & Baik \\
\hline 2. & Komponen RPP & $90,6 \%$ & Baik \\
\hline 3. & $\begin{array}{l}\text { Penyusunan RPP } \\
\text { kecakapan Abad } 21\end{array}$ & $59,3 \%$ & Kurang \\
\hline & Rata-rata & $83,3 \%$ & Baik \\
\hline
\end{tabular}

Tabel 2. Pemahaman Guru terhadap Standar Proses padaTahap Perencanaan

Tabel 3. Pemahan Guru IPA terhadap Standar Proses pada Tahap Pelaksanaan

\begin{tabular}{|c|l|l|l|}
\hline No & $\begin{array}{l}\text { Pemahaman ter- } \\
\text { hadap pelaksanaan } \\
\text { Kurikulum 2013 }\end{array}$ & $\begin{array}{l}\text { Pre- } \\
\text { sentase }\end{array}$ & Kriteria \\
\hline 1. & $\begin{array}{l}\text { Kegiatan pen- } \\
\text { dahuluan mem- } \\
\text { berikan motivasi }\end{array}$ & $96,8 \%$ & Baik \\
\hline 2. & $\begin{array}{l}\text { Kegiatan pen- } \\
\text { dahuluan mem- } \\
\text { berikan persepsi }\end{array}$ & $90,6 \%$ & Baik \\
\hline 3. & $\begin{array}{l}\text { Materi } \\
\text { pembelajaran }\end{array}$ & $81,2 \%$ & Cukup \\
\hline 4. & Kegiatan inti & $84,3 \%$ & Baik \\
\hline
\end{tabular}




\begin{tabular}{|c|l|l|l|}
\hline & $\begin{array}{l}\text { kecakapan berpikir } \\
\text { kritis }\end{array}$ & & \\
\hline 5. & $\begin{array}{l}\text { Kegiatan inti } \\
\text { kecakapan } \\
\text { komunikasi }\end{array}$ & $71,8 \%$ & Cukup \\
\hline 6. & $\begin{array}{l}\text { Kegiatan inti } \\
\text { kecakapan } \\
\text { kreativitas }\end{array}$ & $65,6 \%$ & Cukup \\
\hline 7. & $\begin{array}{l}\text { Kegiatan inti } \\
\text { kecakapan } \\
\text { kolaborasi }\end{array}$ & $75 \%$ & Cukup \\
\hline 8. & $\begin{array}{l}\text { Model } \\
\text { pembelajaran }\end{array}$ & $75 \%$ & Cukup \\
\hline 9. & $\begin{array}{l}\text { Media } \\
\text { pembelajaran }\end{array}$ & $75 \%$ & Cukup \\
\hline 10. & Sumber belajar & $90,6 \%$ & Baik \\
\hline 11. & $\begin{array}{l}\text { Kegiatan penutup } \\
\text { menyimpulkan ma- } \\
\text { teri pelajaran }\end{array}$ & $96,8 \%$ & Baik \\
\hline 12. & $\begin{array}{l}\text { Kegiatan penutup } \\
\text { memberikan } \\
\text { kesempatan } \\
\text { untuk bertanya } \\
\text { kembali }\end{array}$ & $87,5 \%$ & Baik \\
\hline 13. & $\begin{array}{l}\text { Kegiatan penutup } \\
\text { memberikan } \\
\text { kegiatan tindak } \\
\text { lanjut }\end{array}$ & $87,5 \%$ & Baik \\
\hline 14. & $\begin{array}{l}\text { Kegiatan penutup } \\
\text { menginformasikan } \\
\text { materi pelajaran } \\
\text { untuk pertemuan } \\
\text { berikutnya }\end{array}$ & $96,8 \%$ & Baik \\
\hline & Rata-rata & $85,2 \%$ & Baik \\
\hline
\end{tabular}

Tabel 4. Pemahaman Guru IPA terhadap Standar Penilaian pada Tahap Perencanaan

\begin{tabular}{|l|l|l|l|}
\hline No & $\begin{array}{l}\text { Pemahaman ter- } \\
\text { hadap pelaksanaan } \\
\text { Kurikulum 2013 }\end{array}$ & $\begin{array}{l}\text { Pre- } \\
\text { sentase }\end{array}$ & Kriteria \\
\hline 1. & $\begin{array}{l}\text { Tujuan penilaian } \\
\text { autentik }\end{array}$ & $75 \%$ & Cukup \\
\hline 2. & $\begin{array}{l}\text { Mekanisme } \\
\text { penilaian hasil bela- } \\
\text { jar }\end{array}$ & $75 \%$ & Cukup \\
\hline \multicolumn{2}{|c|}{ Rata-rata } & $75 \%$ & Cukup \\
\hline
\end{tabular}

Tabel 5. Pemahaman Guru IPA terhadap Standar Penilaian pada Tahap Pelaksanaan

\begin{tabular}{|l|l|l|l|}
\hline No & $\begin{array}{l}\text { Pemahaman ter- } \\
\text { hadap pelaksanaan } \\
\text { Kurikulum 2013 }\end{array}$ & $\begin{array}{l}\text { Pre- } \\
\text { sentase }\end{array}$ & Kriteria \\
\hline 1. & $\begin{array}{l}\text { Penilaian aspek } \\
\text { pengetahuan }\end{array}$ & $96,8 \%$ & Baik \\
\hline 2. & $\begin{array}{l}\text { Penilaian aspek ket- } \\
\text { erampilan }\end{array}$ & $84,3 \%$ & Baik \\
\hline
\end{tabular}

\begin{tabular}{|c|c|c|c|}
\hline 3. & $\begin{array}{l}\text { Ketuntasan pe- } \\
\text { nilaian }\end{array}$ & $96,8 \%$ & Baik \\
\hline 4. & $\begin{array}{l}\text { Pelaporan hasil } \\
\text { penilaian aspek } \\
\text { pengetahuan } \\
\text { dalam bentuk angka }\end{array}$ & $93,7 \%$ & Baik \\
\hline 5. & $\begin{array}{l}\text { Pelaporan hasil } \\
\text { penilaian aspek } \\
\text { pengetahuan } \\
\text { dalam bentuk } \\
\text { deskripsi }\end{array}$ & $84,3 \%$ & Baik \\
\hline 6. & $\begin{array}{l}\text { Pelaporan hasil } \\
\text { penilaian aspek ket- } \\
\text { erampilan } \\
\text { dalam bentuk angka }\end{array}$ & $93,7 \%$ & Baik \\
\hline 7. & $\begin{array}{l}\text { Pelaporan hasil } \\
\text { penilaian aspek ket- } \\
\text { erampilan } \\
\text { dalam bentuk } \\
\text { deskripsi }\end{array}$ & $93,7 \%$ & Baik \\
\hline 8. & Pedoman penilaian & $90,6 \%$ & Baik \\
\hline & Rata-rata & $91,7 \%$ & Baik \\
\hline
\end{tabular}

\section{Pembahasan}

a. Pemahaman Guru IPA terhadap Pelaksanaan Kurikulum 2013

Berdasarkan Tabel 1, terungkap bahwa hasil rata-rata pemahaman guru IPA terhadap pelaksanaan Kurikulum 2013 kelas VII SMP Negeri se-Kecamatan Lima Kaum Kabupaten Tanah Datar yaitu sebesar $73 \%$ dengan kriteria cukup. Nilai tertinggi pada pemahaman guru IPA terhadap pelaksanaan Kurikulum 2013 yaitu sebesar $87,5 \%$ dengan kriteria baik. Nilai terendah pada pemahaman guru IPA terhadap pelaksanaan Kurikulum 2013 yaitu sebesar 62,5\% dengan kriteria cukup.

Dari 8 orang guru yang menjadi sampel penelitian, ada dua orang guru yang tidak menerima informasi perubahan pembelajaran pendekatan saintifik menuju pembelajaran kecakapan Abad 21. Dari wawancara yang peneliti lakukan terungkap bahwa kedua guru tersebut tidak mengikuti sosialisasi sehingga belum mengetahui adanya perubahan pembelajaran pendekatan saintifik menuju pembelajaran kecakapan Abad 21. Kemendikbud (2016) menyatakan dengan terlibat secara aktif pada pelatihan terkait Kurikulum 2013, seseorang paling tidak memiliki pengalaman yaitu pemahaman terhadap ide dan desain kurikulum, strategi penyajian implementasi kurikulum, dan menyampaikan konsep kurikulum. 
Ada 3 orang guru yang tidak mengetahui proses pembelajaran kecakapan Abad 21. Ditjen Pendidikan Dasar dan Menengah (2017) menyatakan peserta didik harus dipersiapkan untuk memiliki kualitas karakter yang sesuai dengan tuntutan kompetensi kecakapan Abad 21 meliputi critical thinking and problem solving skill (kecakapan berpikir kritis dan pemecahan masalah), communication skills (kecakapan berkomunikasi), creativity and innovation (kecakapan kreativitas dan inovasi), dan collaboration (kecakapan kolaborasi). Hal ini dikarenakan, guru-guru tidak mengikuti sosialisasi sehingga tidak memahami proses pembelajaran kecakapan Abad 21.

Selanjutnya, terdapat 2 orang guru yang mengetahui tujuan diterapkannya pembelajaran kecakapan Abad 21. Hal ini dikarenakan 2 orang guru ini mengikuti sosialiasi. Oleh karena itu proses sosialisasi perubahan Kurikulum penting dilakukan. Sosialisasi harus dilaksanakan secara merata oleh Dinas Pendidikan. Selain itu guru juga harus memiliki inisiatif serta keinginan untuk mencari tahu perubahan yang terjadi pada Kurikulum 2013. Tujuan diterapkannya pembelajaran Abad 21 bagi guru, menurut Ditjen Pendidikan Dasar dan Menengah (2017) diantaranya adalah untuk meningkatkan pemahaman guru tentang kecakapan Abad 21 dan implementasinya dalam pembelajaran serta untuk meningkatkan profesionalisme guru untuk memenuhi tuntutan pengembangan kecakapan peserta didik yang sesuai dengan kecakapan Abad 21.

Selanjutnya, tujuan pendidikan Abad 21 bagi peserta didik adalah untuk mendorong peserta didik agar menguasai keterampilanketerampilan Abad 21 yang penting dan berguna bagi mereka agar lebih responsif terhadap perubahan dan perkembangan jaman (Afandi, J.T, dan R. Afriani, 2016). Guru belum memperoleh infromasi kecakapan Abad 21, sehingga guru tidak memahami proses pembelajaran kecakapan Abad 21 dan tujuan pembelajaran kecakapan Abad 21 dikarenakan guru tidak mengikutisosialisasi. Oleh karena itu, sosialisasi penting dilaksanakan. Sebagimana Fitriany dan Susilo (2014) menyatakan strategi yang digunakan oleh guru dalam menghadapi penerapan Kurikulum 2013 yakni dengan guru bertanya kepada rekan sesama guru terutama dilakukan dalam kegiatan sosialisasi dengan metode sharing dengan guru yang dianggap mampu memberikan informasi yang dibutuhkan, mencari buku referensi yang digunakan sebagai sumber kegiatan pembelajaran, serta mencari informasi dengan browsing dari internet sebagai salah satu bentuk usaha dalam menambah pengetahuan dengan memanfaatkan kemajuan teknologi.

b. Pemahaman Guru IPA terhadap Standar Proses pada Tahap Perencanaan

Berdasarkan Tabel 2, terungkap bahwa hasil nilai rata-rata pemahaman guru IPA terhadap standar proses pada tahap perencanaan yaitu sebesar $83,3 \%$ dengan kriteria baik. Nilai tertinggi pemahaman guru IPA terhadap standar proses pada tahap perencanaan yaitu sebesar $100 \%$ dengan kriteria baik. Nilai terendah pemahaman guru IPA terhadap standar proses pada tahap perencanaan yaitu sebesar 59,3\% dengan kriteria cukup.

Ada dua orang guru yang mengetahui penyusunan RPP kecakapan Abad 21. Hal ini dikarenakan dua orang guru ini mengikuti sosialisasi. Sedangkan terdapat enam orang guru yang tidak mengetahui penyusunan RPP kecakapan Abad 21 dikarenakan guru tidak mengikuti sosialisasi. Dikarenakan belum memperoleh informasi, guru-guru yang tidak mengikuti sosialiasi tidak memahami adanya perubahan proses pembelajaran pendekatan saintifik menuju pembelajaran kecakapan Abad 21 , proses pembelajaran $4 \mathrm{C}$, contohnya guru belum melaksanakan kegiatan kompetensi kecakapan komunikasi, kecakapan kreativitas, dan kecakapan kolabrasi, dan guru tidak mengetahui tujuan diterapkannya pembelajaran kecakapan Abad 21. Sosialiasi tentang perubahan kecakapan Abad 21 tidak merata dilakukan oleh Dinas Pendidikan, sosialisasi dilakukan untuk sekolah-sekolah yang baru menerapkan Kurikulum 2013.

Dari hasil analisis data penelitian berupa RPP yaitu metode pembelajaran yang dipakai masih menggunakan metode ceramah dan diskusi kelompok, di RPP guru menuliskan menggunakan media berbasis IT tetapi pada pelaksanaannya tidak menggunakan media belajar berbasis IT berupa (OHP, LCD, laptop/computer). Sedangkan terdapat enam orang guru yang paham model pembelajaran Kurikulum 2013. Namun jika dilihat secara terperinci dari angket pertanyaan 17 dan 18 menyatakan guru belum memahami model pembelajaran yang direkomendasikan pada Kurikulum 2013 contohnya guru kesulitan mengatur peserta didik dalam menerapkan 
model pembelajaran yang direkomendasikan Kurikulum 2013 sehingga guru menerapkan model pembelajaran KTSP, guru hanya menyebutkan dua model pembelajaran yang direkomendasikan Kurikulum 2013 sedangkan model pembelajaran pada Kurikulum 2013 menurut Kemendikbud (2016) menyatakan model pembelajaran yang dapat digunakan untuk merealisasikan pendekatan pembelajaran kontekstual adalah pembelajaran dengan metode ilmiah (discovery/ inquiry learning), pembelajaran berbasis proyek (project based learning), dan pembelajaran berbasis masalah (problem based learning).

Selanjutnya, ada enam orang guru sering mempersiapkan media belajar ketika akan melaksanakan proses pembelajaran. Berdasarkan hasil angket pertanyaan 20 menyatakan ada 4 orang guru yang tidak menggunakan media pembelajaran berupa media berbasis teknologi dan informasi (OHP, LCD, laptop/computer). Kebanyakan guru menggunakan media berupa alat peraga pendidikan dikarenakan sarana dan prasarana pendukung disekolah belum memadai sehingga guru tidak menggunakan media berbasis IT. Sejalan dengan pendapat Afifah. N, D. Sayuti, dan Parmono (2017) menyatakan problematika pelaksanaan Kurikulum 2013 di Kecamatan Rambah Hilir Riau yaitu guru tidak pernah menggunakan media pembelajaran di kelas dikarenakan sarana dan prasarana pendukung disekolah belum memadai.

Proses pembelajaran Abad 21 mengharuskan guru untuk menggunakan media pembelajaran berbasis IT. Menurut Wijaya, Y.E, A.D. Sudjimat, dan A. Nyoto, (2016) "Keterampilan yang menjadi fokus kompetensi pembelajaran pada abad 21 adalah keterampilan dalam menguasai media teknologi dan infromasi (TIK)". Guru harus terampil dalam menggunakan media teknologi dan informasi (TIK) agar semua peserta didik tahu tentang laptop/komputer dan menjadi akrab dengan komputer untuk meningkatkan pengajaran dan pembelajaran.

c. Pemahaman Guru IPA terhadap Standar Proses pada Tahap Perlaksanaan

Berdasarkan Tabel 3, terungkap bahwa hasil nilai rata-rata pemahaman guru IPA terhadap standar proses pada tahap pelaksanaan yaitu sebesar $85,2 \%$ dengan kriteria baik. Nilai tertinggi pemahaman guru IPA terhadap standar proses pada tahap pelaksanaan yaitu sebesar
96,8\% dengan kriteria baik. Nilai terendah pemahaman guru IPA terhadap standar proses pada tahap pelaksanaan yaitu sebesar $65,6 \%$ dengan kriteria cukup.

Ada dua orang guru yang belum melaksanakan proses pembelajaran yang mengembangkan kecakapan komunikasi. Ada 4 orang guru tidak melaksanakan proses pembelajaran yang mengembangkan kecakapan kretivitas, selanjutnya dua orang guru belum melaksanakan proses pembelajaran yang mengembangkan kecakapan kolaborasi. Hal ini dikarenakan guru kurang memperoleh informasi mengenai perubahan pembelajaran pendekatan saintifik menuju pembelajaran Abad 21, guru kurang memahami proses pembelajaran kecakapan Abad 21, serta guru kurang memahami tujuan diterapkannya pembelajaran kecakapan Abad 21 sehingga pada pelaksanaan proses pembelajaran, guru belum melaksanakan kegiatan 4C yang meliputi kecakapan komunikasi, kecakapan kreativitas, dan kecakapan kolaborasi. Berdasarkan hasil angket dan analisis dokumen RPP didapatkan hasil permasalahan yang sama yaitu guru belum melaksanakan kegiatan 4C.

Dari hasil analisis data penelitian yaitu RPP ada beberapa komponen yang belum sesuai dengan penyusunan RPP Abad 21, yaitu dari segi pelaksanaan proses pembelajaran guru tidak melakukan kegiatan pendahuluan berupa motivasi dan apersepsi terlebih dahulu. Berdasarkan hasil analisis data penelitian berupa RPP pada kegiatan inti, guru belum memunculkan kegiatan kompetensi kecakapan komunikasi, kecakapan kreativitas, dan kecakapan kolaborasi.

d. Pemahaman Guru IPA terhadap Standar Penilaian pada Tahap Perencanaan

Berdasarkan Tabel 4, terungkap bahwa hasil nilai rata-rata pemahaman guru IPA terhadap standar penilaian pada tahap perencanaan yaitu sebesar $75 \%$ dengan kriteria cukup. Nilai tertinggi pemahaman guru IPA standar penilaian pada tahap perencanaan yaitu sebesar $75 \%$ dengan kriteria cukup. Nilai terendah pemahaman guru IPA standar penilaian pada tahap perencanaan yaitu sebesar $75 \%$ dengan kriteria cukup.

ada enam orang guru paham tentang tujuan penilaian autentik Kurikulum 2013. Permendikbud 23 Tahun 2016 menyatakan penilaian hasil belajar oleh pendidik bertujuan untuk mematau dan mengevakuasi hasil belajar 
peserta didik secara berkesinambungan. Dengan demikian, guru harus memahami tujuan penilaian pada Kurikulum 2013. Selanjutnya, ada enam orang guru paham mekanisme penilaian hasil belajar. Permendikbud 23 Tahun 2016 menyatakan mekanisme penilaian hasil belajar oleh pendidik meliputi perancangan strategi penilaian pada saat penyusunan RPP, penilaian aspek sikap, penilaian aspek pengetahuan, penilaian aspek keterampilan, peserta didik yang belum mencapai KKM dan hasil penilaian capaian pengetahuan dan keterampilan dalam bentuk angka dan deskripsi.

e. Pemahaman Guru IPA terhadap Standar Penilaian pada Tahap Pelaksanaan

Berdasarkan Tabel 5, terungkap bahwa hasil nilai rata-rata pemahaman guru IPA terhadap standar penilaian pada tahap pelaksanaan yaitu sebesar $91,7 \%$ dengan kriteria baik. Nilai tertinggi pemahaman guru IPA terhadap standar penilaian pada tahap pelaksanaan yaitu sebesar 96,8\% dengan kriteria baik. Nilai terendah pemahaman guru IPA terhadap standar proses pada tahap pelaksanaan yaitu sebesar $84,3 \%$ dengan kriteria baik.

Dari hasil analisis data penelitian berupa RPP yaitu dari segi penilaian, pada RPP guru menuliskan penilaian pengetahuan dan keterampilan tetapi guru tidak melampirkan instrumen penilaian pada aspek pengetahuan maupun aspek keterampilan.

Berdasarkan hasil angket ada tujuh orang guru selalu melakukan penilaian aspek pengetahuan. Namun jika dilihat secara terperinci dari angket pertanyaan 29 , yaitu masih terdapat guru yang belum memahami teknik penilaian yang digunakan dalam mengukur pencapaian pengetahuan. Permendikbud 23 Tahun 2016 menyatakan teknik penilaian mengukur aspek pengetahuan meliputi instrumen tes tertulis, tes lisan, dan penugasan. Contoh problematikanya yaitu dari tiga komponen penilaian aspek pengetahuan, guru hanya memahami satu jenis teknik penilaian aspek pengetahuan yaitu instrumen tes tertulis, guru tidak sesuai menggunakan teknik penilaian aspek pengetahuan dengan apa yang dinilai yaitu guru menggunakan instrumen observasi untuk menilai aspek pengetahuan. Selanjutnya, guru tidak sesuai menggunakan teknik penilaian aspek pengetahuan dengan apa yang dinilai yaitu guru menggunakan instrumen penilaian proyek, penilaian produk, penilaian portofolio untuk menilai aspek pengetahuan.
Berdasarkan hasil angket ada lima orang guru sering melakukan penilaian aspek keterampilan. Namun jika dilihat secara terperinci dari angket pertanyaan 31, guru belum memahami teknik penilaian yang digunakan dalam mengukur pencapaian aspek keterampilan. Permendikbud 23 Tahun 2016 menyatakan Teknik penilaian mengukur keterampilan yaitu teknik penilaian kompetensi keterampilan melalui penilaian praktik, penilaian produk, penilaian proyek, dan penilaian portofolio. Contoh problematikanya yaitu, dari empat komponen penilaian aspek keterampilan, guru hanya mengetahui tiga komponen penilaian aspek keterampilan yaitu penilaian praktik, penilaian produk, dan penilaian proyek. Guru tidak sesuai menggunakan teknik penilaian aspek keterampilan dengan apa yang dinilai yaitu guru menggunakan instrumen penugasan untuk menilai aspek keterampilan, guru tidak menuliskan capaian penilaian aspek keterampilan dalam bentuk deskripsi, dan guru tidak melampirkan instrumen penilaian aspek pengetahuan dan aspek keterampilan, guru hanya menuliskan saja instrumen penilaian yang digunakan untuk menilaian aspek pengetahuan dan aspek keterampilan.

\section{KESIMPULAN}

1. Pemahaman guru IPA terhadap pelaksanaan Kurikulum 2013 berdasarkan standar proses yaitu $80,5 \%$ dengan kriteria baik.

2. Pemahaman guru IPA terhadap pelaksanaan Kurikulum 2013 berdasarkan standar peni laian yaitu 83,4\% dengan kriteria baik.

\section{DAFTAR PUSTAKA}

Afifah, N., Sayuti D., \& Pramono. (2017). Problematika Pelaksanaan Kurikulum 2013 pada Proses Pembelajaran Biologi Kelas VII SMP di Kecamatan Rambah Hilir. Jurnal Inovasi Pendidikan. 1 (17), 185.

Afriana, J., Permanasari, A., \& Fitriani, A. (2016). Penerapan Project Based Learning Terintegrasi STEM untuk Meningkatkan Literasi Sains Siswa Ditinjau dari Gender. Jurnal Inovasi Pendidikan. 2 (2), 203.

Afandi, J. T., \& Afriani, R. (2016). Implementasi Digital-Age Literacy dalam Pendidikan Abad 21 di Indonesia. Prosiding Seminar Nasional Pendidikan Sains (SNPS). 22 Oktober 2016.

Arikunto. (2007). Prosedur penelitian suatu pendekatan praktik. Jakarta: Rineka Aksara. 
Ditjen Pendidikan Dasar dan Menengah. (2017). Panduan Implementasi Kecakapan Abad 21 Kurikulum 2013 Di Sekolah Menengah Atas. Jakarta: Kementerian Pendidikan dan Kebudayaan.

Fitriany, R. A. M., \& Susilo, H. (2014). Analisis Hambatan Proses Pembelajaran Biologi dan Cara Pemecahannya dalam Pelaksanaan Kurikulum 2013 Bagi Guru Kelas X SMA Negeri Se-Kota Lamongan. Jurnal Pendidikan Biologi. FMIPA Universitas Negeri Malang.

Kunandar. (2015). Penilaian Autentik (Penilaian Hasil Belajar Peserta Didik Berdasarkan Kurikulum 2013). Jakarta: PT Rajagrafindo Persada.

Lukum, A. (2015). Evaluasi Program Pembelajaran IPA SMP Menggunakan Model Countenance Stake. Jurnal Penelitian dan Evaluasi Pendidikan. 19 (1), 26.

Mulyasa, E. (2014). Pengembangan dan Implementasi Kurikulum 2013. Bandung: PT. Remaja Rosdakarya.

Peraturan Menteri Pendidikan dan Kebudayaan. (2016). Peraturan Menteri Pendidikan Na- sional Republik Indonesia Nomor 22 Tahun 2016 Tentang Kerangka Dasar dan Struktur Kurikulum. Jakarta: Badan Standar Nasional Pendidikan. . (2016). Peraturan Menteri Pendidikan Nasional Republik Indonesia Nomor $23 \mathrm{Ta}$ hun 2016 Tentang Kerangka Dasar dan Struktur Kurikulum. Jakarta: Badan Standar Nasional Pendidikan.

Rahmi, L.Y., \& Alberida, H. (2017). Improving Students' Higher Order Thinking Skills through Portfolio Assessment on Biology Curriculum and Textbook Analysis Course. Bioeducation Journal. 1 (1), 22-33.

Sudjana. (2005). Metode Statistika. Bandung: Tarsito.

Vusparatih, S.D. (2014). Peranan Komunikasi Guru Dalam Implementasi Kurikulum 2013. Jurnal Humaniora. 5 (1), 391.

Wijaya, Y. E., Sudjimat, A. D., \& Nyoto, A. (2016). Transformasi Pendidikan Abad 21 Sebagai Tuntutan Pengembangan Sumber Daya Manusia Di Era Global. Jurnal Prosiding Seminar Nasional Pendidikan Matematika 2016. 1, 264-277. 